\title{
My Learned Helplessness is Accelerating to Self-Handicapping
}

\author{
Yener Özen* \\ Department of Educational Sciences, Kyrgyzstan-Turkey Manas University, Turkey
}

Submission: February 22, 2020; Published: March 18, 2020

*Corresponding author: Yener Özen, Department of Educational Sciences, Manas University, Kyrgyzstan Turkey

\begin{abstract}
Individuals' ability to have a healthy mental structure depends on their ability to maintain high self-esteem. In order to achieve this, it depends on their ability to successfully fulfill the tasks and responsibilities they have taken in life. When individuals fail to accomplish the tasks, they are responsible for, they will feel mentally and incapacitated. This will lower the self-esteem of individuals. This will cause individuals to be unhappy and uneasy and to feel guilty. When individuals do not want themselves to be known as incompetent, untalented and lazy, there are strategies to take refuge in. The two most important strategies are learned helplessness and self-handicapping. Individuals who do not have a healthy mental structure try to cover up their mistakes and irresponsibility in their tasks by using these two strategies. Individuals using this strategy often depend on the focus of external control. Their failure is due to fate, fortune, parents who do not educate him, teachers, and God. In this study, the learned helplessness literature from 1967 to this side and self-handicapping literature from 1978 to this side are overhauled to show how learned helplessness is transformed into self-handicapping.
\end{abstract}

Keywords: Self helplessness; Self-handicapping; Self-image; Self-esteem

\section{Introduction}

Learned helplessness is behavior exhibited by a subject after enduring repeated aversive stimuli beyond their control. It was initially thought to be caused from the subjectss acceptance of their powerlessness: discontinuing attempts to escape or avoid the aversive stimulus, even when such alternatives are unambiguously presented. Upon exhibiting such behavior, the subject was said to have acquired learned helplessness. Over the past few decades, neuroscience has provided insight into learned helplessness and shown that the original theory actually had it backwards: the brain's default state is to assume that control is not present, and the presence of "helpfulness" is what is actually learned [1]. In humans, learned helplessness is related to the concept of self-efficacy, the individual's belief in their innate ability to achieve goals. Learned helplessness theory is the view that clinical depression and related mental illnesses may result from such real or perceived absence of control over the outcome of a situation [2].

Self-handicapping is a cognitive strategy by which people avoid effort in the hopes of keeping potential failure from hurting self-esteem. It was first theorized by Edward E. Jones and Steven Berglas, according to whom self-handicaps are obstacles created, or claimed, by the individual in anticipation of failing performance
[3]. Self-handicapping can be seen as a method of preserving selfesteem but it can also be used for self-enhancement and to manage the impressions of others. This conservation or augmentation of self-esteem is due to changes in causal attributions or the attributions for success and failure that self-handicapping affords. There are two methods that people use to self-handicap: behavioral and claimed self-handicaps. People withdraw effort or create obstacles to successes so they can maintain public and private self-images of competence [4].

Sameer Babu M \& Selvamari S [5] defines self-handicapping as "a process of employing unique verbal and/or non-verbal strategies of carelessness on, lethargy in, and withdrawal from the academic duties and responsibilities which leads to lower academic standards". Self-handicapping is a widespread behavior amongst humans that has been observed in a variety of cultures and geographic areas. For instance, peoples frequently participate in self-handicapping behavior to avoid feeling bad about them if they do not perform well in class. Self-handicapping behavior has also been observed in the business world. The effects of selfhandicapping can be both large and small and found in virtually any environment wherein people are expected to perform. As a form of procrastination, academic procrastination is a prevalent 
self-handicapping strategy among academics in the face of academic tasks. It has been associated with lower academic motivation and self-regulation and decrease in academic efficacy and achievement. Therefore, understanding the nature of this phenomenon could enhance the academic outcomes of academics.

\section{Is helplessness learned?}

American psychologist Martin Seligman initiated research on learned helplessness in 1967 at the University of Pennsylvania as an extension of his interest in depression [6]. This research was later expanded through experiments by Seligman and others. One of the first was an experiment by Seligman \& Maier: In Part 1 of this study, three groups of dogs was placed in harnesses. Group 1 dogs were simply put in a harness for a period of time and were later released. Groups 2 and 3 consisted of "yoked pairs". Dogs in Group 2 were given electric shocks at random times, which the dog could end by pressing a lever. Each dog in Group 3 was paired with a Group 2 dog; whenever a Group 2 dog got a shock, its paired dog in Group 3 got a shock of the same intensity and duration, but its lever did not stop the shock. To a dog in Group 3, it seemed that the shock ended at random, because it was their paired dog in Group 2 that was causing it to stop. Thus, for Group 3 dogs, the shock was "inescapable". In Part 2 of the experiment the same three groups of dogs were tested in a shuttle-box apparatus (a chamber containing two rectangular compartments divided by a barrier a few inches high). All of the dogs could escape shocks on one side of the box by jumping over a low partition to the other side. The dogs in Groups 1 and 2 quickly learned this task and escaped the shock. Most of the Group 3 dogs - which had previously learned that nothing they did had any effect on shocks - simply lay down passively and whined when they were, shocked [2].

The basis of Seligman's personality theory is derived from his first interaction with learned helplessness. Seligman defines helplessness as an intuitive notion that entails the belief that nothing one does will matter; one believes that their actions are futile [1]. Through multiple experiments with dogs, Seligman solidified his theories on learned helplessness when repeated results of passiveness and helplessness were found. Using these results of learned helplessness, Seligman developed his personality theory, which employed two explanatory styles - optimistic and pessimistic. Basically, if a person adopts an optimistic explanatory style, he/she will prevent helplessness; if he/she adopts a pessimistic explanatory style, then helplessness will be spread through all facets of life [7].

Optimistic people typically attribute problems in their lives as temporary, specific, and external. Pessimistic people typically attribute problems in their lives as permanent, pervasive, and internal. An optimistic explanatory style is related to higher levels of motivation, achievement, and physical wellbeing, along with lower levels of depressive symptoms [8]. These explanatory styles are important when it comes to defining a person's personality. They also can have a significant impact on the health of an individual. The brain is probably more comfortable where it always knows it and tries to maintain this familiar situation as much as possible. The brain has adjusted its entire system to the current situation. Even if there is a tiny, tiny change in its condition, it has to change all its processes to adapt to this new state again. So, the first reaction of the brain to change is to show as much resistance as possible. Because it's neutral about the problems in its system. It does not qualify as positive or negative. It just tries to keep his system in balance. Self-Handicapping is more or less common. We all have an upper threshold, a level of happiness that it cannot handle. The important thing is whether the window is narrow or wide? This window affects both thresholds. Those who have a low tolerance for happiness are also more intolerant of adversity. The simplest way to be happy is to stop looking for happiness, to experience it.

\section{The Path from Learned Helplessness to Self- Handicapping}

The concept of learned helplessness defines an escape or avoidance deficit after uncontrollable stress and is regarded as a depression-like coping deficit in aversive but avoidable situations. Based on a psychological construct, it ideally complements other stress-induced or genetic animal models for major depression. Because of the excellent face, construction and predictive validity, it has contributed to the elaboration of several pathophysiological concepts and has brought forward new treatment targets [9]. Selfhandicapping behavior allows individuals to externalize failures but internalize success, accepting credit for achievements but allowing excuses for failings. An example of self-handicapping is the people who spend the night before an important exam partying rather than studying. The student fears to fail his exam and appearing incapable. In partying the night before the exam, the student has engaged in self-defeating behavior and increased the likelihood of poor exam performance. However, in the event of failure, the student can offer fatigue and a hangover, rather than lack of ability, as plausible explanations. Furthermore, should the student receive positive feedback about his exam, his achievement is enhanced by the fact that he succeeded, despite the handicap.

According to the (DSM-III R), describes Self-Handicapping Personality Disorder as: "A pervasive pattern of self-handicapping behavior, beginning by early adulthood, and present in a variety, of contexts" [10]. The person may often avoid or undermine pleasurable experiences, be drawn to situations or relationships in which he or she will suffer and prevent others from helping him or her. This personality disorder is exhibited through behaviors that are harmful or defeating and provokes a negative response from the behaving individual's physical or social environment [11]. Those with self-handicapping personalities are more apt to place themselves in situations in which they are defeated and helpless. The results of such experiences are likely to cause them to make attributions consistent with the theory of learned helplessness. 
Learned helplessness results when feelings of incompetence are acquired which are often from repeated failure experiences [12] and, usually follow in the wake of uncontrollable events [11]. The thoughts and attributions which are acquired are typically internal (It's my fault), stable (It's going to last forever), and global (It's going to undermine everything I do). It was further discussed in Abramson, Seligman, \& Teasdale's study [13] that the generalization of expectations of uncontrollability across time and tasks depends on the attributions the person makes for their failure.

Seligman [2] developed a scale to assess the theory of learned helplessness. The questionnaire consists of 12 hypothetical good and bad events pertaining to achievement and affiliation. In each case, subjects are asked to imagine the event happening to them. They then write the one major cause of the event and rate it in terms of internal (something about the person) or external (something about the situation) explanations; internal explanations are associated with a loss of self-esteem; stable (non-transient factors) or unstable (transient) explanations for bad events; stable explanations are associated with long lasting helplessness deficits; and global (various situations/tasks) or specific (circumscribed cause) explanations of bad events; global being associated with pervasive deficits $[13,14]$.

In these studies, attempted to determine whether or not the more self-handicapping a person is, the more learned helplessness whether they were found. Given their chronic self-handicapping patterns that fail to lead to reinforcements in achievement and interpersonal situations one would expect that the stronger peoples, the more characteristics they have found of learned helplessness [15]. Oddly, we often neglect the impact of emotions on the learning process. Humans are emotion-driven animals and our emotional behavior has developed at part of the evolutionary process, so why would we overlook such a vital part of the jigsaw. There are many ways that emotions might help or hinder learning in our students - and some of them might surprise you [16].

While the relationship between fear of failure, selfhandicapping, and academic achievement is complex; researches do tend to agree that those students with higher levels of fear of failure are more likely to employ self-handicapping strategies. Academic self-handicapping (or academic self-sabotage) relates to pre-emptive strategies used by students to avoid failure and safeguard self-esteem. For example, a student might say they were ill so they couldn't revise for the test - this makes any failure the results of 'being ill' rather than not being "clever enough" [17]. In order for peoples to be successful in their jobs and to fulfill their duties and responsibilities effectively, they should love themselves, accept themselves and respect themselves, in other words, they should have a positive sense of self. In this respect, having a positive sense of self is an aim that individuals always try to achieve. Individuals strive to achieve this goal and sometimes use self-handicapping strategies to protect self-perception. These strategies, which the individual initially uses to protect his / her own self, can harm the self of the individual after a while. In this context, it is important to understand these strategies that are effective in the short term, but which harm the individual in the long term [18]. According to Chen, Sun \& Wang [19], the main objective of individuals avoiding performance is not to be perceived as a failure by the people around them. Therefore, in order to protect their self-esteem, they will connect their failures to the obstacles they put on themselves rather than their abilities. Although the main purpose of learning avoidance orientation is to improve knowledge, abilities, and skills, individuals with this orientation also include fear of not being able to understand or fail. Although the aim of performance-approach orientation is successful, the main factor is the perceptions of others about themselves. As a result, it can be said that individuals with learning-avoidance and performance-approach orientations may change themselves by different environmental conditions and individual factors.

As a result, it can be said that learning-approach orientation, academic external locus of control and performance-avoidance orientation are important variables predicting self-handicapping. In this context, it is possible to stimulate the peoples' feelings of curiosity towards gaining knowledge and skills, to focus on their own personal development and to increase their self-awareness. Therefore, the self-handicapping behaviors of the people's whose internal locus of control is increasing and aiming to gain mastery of success will decrease [20].

\section{Conclusion}

There are some basic motives that are effective in each individual's life and that drive it. One of these motives is to be sufficient and superior. Although individuals are constantly trying to develop themselves under the influence of this motive, they may sometimes experience some psychological problems due to these motives. One of these problems is the negative self-perception that arises due to the perception of inadequacy, Adler (2005). Selfperception is formed by the influence of the social environment experienced in a significant proportion. In this respect, some people succeed by doing the best they can, develop a positive self-perception and are accepted by society. On the other hand, some people fail to succeed, and their self-perception is negatively affected by this [21]. Individuals with this condition use certain strategies to avoid the negative effects of self-perception. One of these strategies is self-handicapping and learned helplessness. The helplessness model has been used to make sense of a variety of failures of human adaptation: depression, academic failure, victimization, athletic setbacks, poor work performance, illness and even early death [22-28]. However, questions can be raised about the reasonableness of some of these applications [28-29]. Some may be too zealous, assuming that each and every instance of observed passivity is the result of the processes hypothesized by the learned helplessness model. 
These ideas provided the point of departure for the present studies, which concerned themselves with helpless behavior and how to conceive it. The learned helpless model defines helplessness in terms of the processes that give rise to it, i.e. uncontrollable events + expectations of response-outcome independence + inappropriate passivity. According to Berglas \& Jones [21], self-handicapping is defined as "all behaviors that provide an opportunity to externalize (or excuse) failure to internalize success." According to Midgley \& Urdan [30], people actively use a strategy of self-sabotage to show that when they think they are going to fail, failure is due to the conditions they are in rather than their own inadequacies. People prefer to be seen as victims of the conditions they are in and do not want to be seen as incompetent and incompetent.

Higgins [31] and Zuckerman, Kieffer \& knee [20], according to the learned helplessness and self-handicapping strategies the ultimate goal of a person's self-esteem and self-efficacy maintain or to increase positive feelings about the self and thus provide a continuum of despite the fact that, after a while, causes a decrease in the success of the individual and personal self-image is damaging. In short, individuals are able to maintain a modicum of their mental health by taking refuge in either learned strategies of desperation or self-handicapping in order to hide their failures and inadequacies and thus protect their self-esteem [32-39].

\section{References}

1. Maier SF, Seligman ME (2016) Learned Helplessness at Fifty: Insights from Neuroscience. Psychol Rev 123(4); 349-367.

2. Seligman MEP (1975) Helplessness: On Depression, Development, and Death. WH Freeman, San Francisco, USA.

3. Feick DL, Rhodewalt F (1997) The Double-Edged Sword of SelfHandicapping: Discounting, Augmentation, and the Protection and Enhancement of Self-Esteem. Motivation and Emotion 21(2): 147-163.

4. Rhodewalt F, Vohs KD (2005) Defensive strategies, motivation, and the self. In A. Elliot \& C. Dweck (Eds.) Handbook of competence and motivation Guilford Press, New York, USA, pp. 548-565.

5. Sameer Babu M, Selvamari S (2018) In: Selvamari S (Ed.), Academic self-concept, self-handicapping, and mastery goal orientation as predictors of achievement in mathematics of secondary school students. Unpublished M Phil Dissertation, University of Kerala, India.

6. Seligman MEP (1972) Learned helplessness. Annual Review of Medicine 23(1): 407-412.

7. Schultz DP, Schultz SE (2009) Martin EP Seligman, Learned Helplessness and the Optimistic/Pessimistic Explanatory Style. In: DP Schultz, SE Schultz (Eds.), Theories of Personality. (10 ${ }^{\text {th }}$ edn), Belmont: Wadsworth: Cengage Learning. pp. 369-378.

8. Gillham JE, Shatte AJ, Reivich KJ, Seligman ME (2001) Optimism, pessimism, and explanatory style. In: EC Chang (Ed.) Optimism \& pessimism: Implications for theory, research, and practice. American Psychological Association, Washington DC, USA, pp. 53-75.

9. O Leary OF, Cryan JF (2013) Towards translational rodent models of depression. Cell Tissue Res 354 (1): 141-153.

10. DSM-IIIR (1987) American Psychiatric Association. (3 $3^{\text {rd }}$ edn), Washington DC, USA.
11. Curtis R (1989) Self- Handicapping. Plenum Press, New York, USA.

12. Vasta R, Haith M, Miller S (1995) Child Psychology. ( $2^{\text {nd }}$ edn), John Wiley \& Sons Inc. New York, USA.

13. Abramson L, Seligman M, Teasdale J (1978) Learned helplessness in humans: Critique and reformulation. J Abnorm Psychol 87: 49-74.

14. Peterson C, Villanova P (1988) An Expanded Atributional Style Questionnaire. J Abnorm Psychol 97: 87-89.

15. Kabatay Regina T (1999) Self-Defeating Personality and Learned Helplessness. Honors Theses.

16. Ames C, Ames R, Felker DW (1977) Effects of competitive reward structure and valence of outcome on children's achievement attributions. Journal of Educational Psychology 69: 1-8.

17. Putwain DW, Daly AL, Chamberlain S, Sadreddini S (2015) Academically buoyant students are less anxious about and perform better in highstakes examinations. Br J Educ Psychol 85(3): 247-263.

18. Stewart MA, De George-Walker L (2014) Self-handicapping, perfectionism, locus of control and self-efficacy: A path model. Personality and Individual Differences 66: 160-164.

19. Chen Z, Sun K, Wang K (2018) Self-esteem, achievement goals, and self-handicapping in college physical education. Psychological Reports 121(4): 690-704.

20.Zuckerman M, Kieffer SC, Knee CR (1998) Consequences of selfhandicapping: Effects on coping, academic performance, and adjustment. Journal of Personality and Social Psychology 74(6): 1619.

21. Berglas S, Jones EE (1978) Control of attributions about the self through self-handicapping strategies: The appeal of alcohol and the role of underachievement. Personality and Social Psychology Bulletin 4(2): 200-206.

22. Peterson C (1990) Explanatory style in the classroom and on the playing field. In: Graham S, Folkes VS (Eds.) Arrriburion theory: Applications or achievement, mental health, and interpersonal conflict Hillsdale. Erlbaum, New Jersey, USA p.53-75.

23. Peterson C, Barrett LC (1987) Explanatory style and academic performance among university freshmen. Journal of Personality and Social Psychology 53: 603-607.

24. Peterson C, Seligman MEP (1983) Learned helplessness and victimization. Journal of Social Issues 39: 103-116.

25. Peterson C, Sehgman MEP (1984) Causal explanations as a risk factor for depression: theory and evidence. Psychological Review 91: 347374.

26. Peterson C, Seligman MEP (1987) Explanatory style and illness. Journal of Personality 55: 237-265.

27. Peterson C, Maier SF, Seligman ME (1993) Learned helplessness: A theory for the age of personal control. Oxford University Press, New York, USA.

28. Peterson C, Zaccaro SJ, Daly DC (1986) Learned helplessness and the generality of social loafing. Cognitive Therapy and Research 10: 563569.

29. Peterson C, Bossio LM (1989) Learned helplessness. In: Curtis RC (Ed.): Self-defeating behaviors Plenum, New York, USA, pp. 235-257.

30. Midgley C, Urdan T (2001) Academic self-handicapping and achievement goals: a further examination. Contemporary Educational Psychology 26: 61-75.

31. Higgins RL (1990) Self-handicapping. Springer, USA, pp. 1-35.

32. Carlson Neil R (2010) Psychology the science of behavior. Pearson, Canada, pp. 409. 
33. Hiroto DS (1974) Locus of control and learned helplessness. Journal of Experimental Psychology, pp.187-193.

34. Hiroto DS, Seligman ME (1975) Generality of Learned Helplessness in Man. Journal of Personality and Social Psychology 31(2): 3111-3127.

35. Peterson C, Villanova P (1988) An expanded attributional style questionnaire. J Abnorm Psychol 97 (I): 87-89.

36. Peterson C, Stunkard AJ (1989) Personal control and health promotion. Social Science and Medicine 28: 819-828.
37. Robinson Whelen S, Kim C, MacCallum RC, Kiecolt-Glaser JK (1997) Distinguishing optimism from pessimism in older adults: Is it more important to be optimistic or not to be pessimistic? Journal of Personality and Social Psychology, pp. 1345- 1353.

38. Seligman ME, Maier SF (1967) Failure to escape traumatic shock. Journal of Experimental Psychology, pp. 1-9.

39. Visintainer MA, Volpicelli JR, Seligman ME (1982) Tumor rejection in rats after inescapable or escapable shock. Science, pp. 437-439.

\section{Your next submission with Juniper Publishers will reach you the below assets}

- Quality Editorial service

- Swift Peer Review

- Reprints availability

- E-prints Service

- Manuscript Podcast for convenient understanding

- Global attainment for your research

- Manuscript accessibility in different formats ( Pdf, E-pub, Full Text, Audio)

- Unceasing customer service

Track the below URL for one-step submission https://juniperpublishers.com/online-submission.php 